\title{
Development of Instruments to Assess Shame and Guilt in Adolescents: Empirical Differences Between the Constructs ${ }^{1}$
}

\author{
Lorena Maria Laskoski ${ }^{2}$ \\ Jean Carlos Natividade \\ Claudio Simon Hutz \\ Universidade Federal do Rio Grande do Sul, Porto Alegre-RS, Brazil
}

\begin{abstract}
Shame and guilt are terms easily mixed in everyday life and often used as synonyms. Although they are words of similar use, they represent theoretically different moral emotions. The aims of this study were to develop and validate instruments to assess shame and guilt and to test the empirical independence of the constructs. Five hundred and eighty high school students from three Brazilian states participated in this study, 55\% of them female, with an average age of 16.0 years. The participants answered a questionnaire containing socio demographic questions and scales designed for this study in order to assess shame and guilt. The scales developed gave appropriate evidence of validity and reliability. A single factor was extracted to assess shame and two factors to assess guilt (recognition of mistake and regret). The constructs revealed to be correlated, but independent. It is considered that there is sufficient evidence to affirm that shame and guilt are emotions with distinctive peculiarities and can be measured using the instruments developed in this research.
\end{abstract}

Keywords: shame, guilt, adolescents, test development

\section{Elaboração de Instrumentos Para Aferir Vergonha e Culpa em Adolescentes: Diferenças Empíricas Entre os Construtos}

\begin{abstract}
Resumo: Vergonha e culpa são termos facilmente confundidos no cotidiano e muitas vezes usados como sinônimos. Embora sejam palavras com usos semelhantes, elas representam emoções morais teoricamente diferentes. Os objetivos deste estudo foram construir e validar instrumentos para avaliar vergonha e culpa e testar a independência empírica dos construtos. Participaram 580 estudantes de Ensino Médio de três Estados brasileiros, 55\% do sexo feminino, média de idade 16,0 anos. Os participantes responderam a um questionário com perguntas sociodemográficas e escalas projetadas para este estudo para aferir vergonha e culpa. As escalas elaboradas apresentaram adequadas evidências de validade e fidedignidade. Um único fator foi extraído para aferir vergonha e para a culpa foram extraídos dois fatores (reconhecimento do erro e arrependimento). Os construtos mostraram-se correlacionados, mas independentes. Considera-se haver evidências suficientes para sustentar que vergonha e culpa são emoções com peculiaridades distintivas e são passíveis de serem aferidas com os instrumentos construídos neste estudo.
\end{abstract}

Palavras-chave: vergonha, culpa, adolescentes, construção do teste

\section{Elaboración de Instrumentos Para Evaluar la Vergüenza y la Culpa en los Adolescentes: Diferencias Empíricas Entre los Constructos}

\begin{abstract}
Resumen: Vergüenza y culpa son términos que se confunden fácilmente en la vida cotidiana y muchas veces son utilizados como sinónimos. Aunque sean palabras con propósitos similares, representan emociones morales teóricamente diferentes. Los objetivos de este estudio fueron construir y validar instrumentos para evaluar vergüenza y culpa y testar la independencia empírica de los constructos. Participaron 580 estudiantes del secundario en tres Estados brasileños, 55\% mujeres, edad promedia 16,0 años. Los participantes respondieron un cuestionario con preguntas demográficas y las escalas creadas en este estudio para evaluar vergüenza y culpa. Las escalas elaboradas presentaron evidencias adecuadas de validez y confiabilidad. Un único factor para evaluar vergüenza fue extraído y para culpa fueron dos factores (reconocimiento de erros y arrepentimiento). Los constructos se mostraran correlacionados, pero independientes. Se considera haber pruebas suficientes para sostener que vergüenza y culpa son emociones que demuestran peculiaridades distintivas e que pueden medirse con los instrumentos construidos en esta investigación.
\end{abstract}

Palabras clave: vergüenza, culpa, adolescente, construcción de test

\footnotetext{
1 Article originated from the thesis presented by the first author at the MsC, under the advice of the last author, presented to the Graduate Program in Psychology of the Universidade Federal do Rio Grande do Sul in 2012.

2 Correspondence address:

Lorena Maria Laskoski. Laboratório de Mensuração, Instituto de Psicologia, Universidade Federal do Rio Grande do Sul. Rua Ramiro Barcelos, 2600, sala 101, Bairro Santa Cecília. CEP 90035-003. Porto Alegre-RS, Brazil. E-mail: lorelaskoski@gmail.com
}

Shame and guilt are terms easily mixed in everyday life and often used as synonyms. These two emotions are part of the same group of emotions: the so-called self-conscious emotions, which are represented in the conscience (La Taille, 2006; Santos, 2009). They are also called moral emotions (Costa, 2008; Paludo, 2002, 2008). The self-conscious or moral emotions involve complex cognitive processes (Santos, 2009), such as: representation of the self (Anolli, 2003); 
understanding of social standards, rules and objectives (Santos, 2009); and also overall assessment of people about themselves and their own behavior in relation to the standards, rules and social objectives, assessing themselves in relation to the failure or violation of standards (Santos, 2009).

Besides being commonly mixed in everyday life, some argue that these emotions are at opposite ends on a continuum (Imber-Black, 1994). From this perspective, people would necessarily feel shame or guilt in relation to events that triggered these emotions. On the other hand, some argue that the distinctions between these two emotions are related to the degree of exposure to other people that some events generating these emotions may cause (Anolli, 2003). In this sense, shame could be classified as a public emotion, resulting from public exposure, and guilt as a private emotion, without being exposed to others. Such ideas about shame and guilt have been confronted with empirical results that suggest that it is possible to feel both emotions regarding the same event.

Tangney, Stuewig e Mashek (2007) tested the effect of shame and guilt events and found no relationship between the emotion triggered and the fact that other people were aware of the failures in performing an action, a situation hypothetically related to guilt. These findings are in accordance with the proposal presented by Lewis (2008), which distinguished shame and guilt by the way people experience these emotions. According to her, shame is be associated with a negative self-assessment and guilt with an assessment of a behavior or action. Based on that logic, to feel ashamed, people would make a comprehensive assessment of their personality (the self) as being bad, while guilt would relate to assessments of the features or unsuccessful specific acts or to a behavior seen as a failure.

Tangney et al. (2007) also found, through interviews, that people who reported events in which they felt ashamed were concerned with the assessment of other people made about themselves. But those who described the guilt emotion were concerned with their effect on others. The authors concluded that shame is related to an assessment of someone's self, especially to negative self-assessments related to concerns about the assessments others may make. Guilt, on the other hand, is linked to a specific behavior considered as negative.

From another perspective, based on the causal attribution theory, Tracy and Robins (2006) explained these emotions departing from causes viewed as triggering these emotions, that is, how or whom people attribute the cause of an event to. According to that theory, people use explanations concerning internal, dispositional causes - related to the self, or external, situational - related to the social or physical circumstances, to explain the events that occur with them (Kelley, 1973); Dela Coleta and Dela Coleta (2011) further address the attributional style theory and its current developments. Tracy and Robins found that there were no differences between shame and guilt in relation to the internal or external attributions and that both of these emotions are characterized by internal attributions. However, differences were found when comparing stability and controllability. Thus, people who understand that a negative event occurred as a result of stable and global characteristics experience shame. However, guilt is experienced when there is an understanding that a negative event occurred as a result of unstable and specific attributions.

Shame is often associated with conditions of psychological imbalance, showing positive correlations with depression, anxiety and even suicide (Tangney \& Tracy, 2012). When feeling ashamed, people also experience feelings of worthlessness, inability (Costa, 2008), powerlessness and incompetence (Stoeber, Harris, \& Moon, 2007). This emotion also shows negative correlations with self-esteem (Tangney, Wagner, Fletcher, \& Gramzow, 1992) and positive correlations with stress levels (Woien, Ernst, Patock-Peckham, \& Nagoshi, 2002).

In contrast, guilt is understood as maladaptive when people develop an excessive or distorted sense of responsibility (Tangney \& Tracy, 2012). The feelings of regret and remorse accompany this emotion, and may motivate those affected by it to repair the act that triggered the guilt (Stoeber et al., 2007). Unlike shame which, when triggered, does not result in motivation for repair (Lewis, 2008), guilt leads people to seek to repair the damage caused to others in order to stop the discomfort caused by the emotion, or even to attempt to reestablish a balance (Krebs, 2008; Wright, 1971). In the opinion of Costa (2008), when people feel guilty, often, a concern with a specific violation is revealed, as well as the desire that such violation had never occurred, or could be undone.

Robinson, Roberts, Strayer and Koopman (2007) conducted a study about empathy and emotional responsiveness among Canadian adolescents. In that study, the authors investigated 64 institutionalized and 60 non-institutionalized high school adolescents. While comparing the two groups concerning shame and guilt, the authors found that there is little difference between the groups with respect to the proneness to these emotions. When these emotions were analyzed within the groups, the researchers found that shame was positively associated with self-reports of anti-social attitudes and behaviors. In contrast, guilt was rarely associated with self-reports of anti-social attitudes and behaviors.

Tangney and Dearing (2004) highlighted in their extensive review of this topic that several instruments are intended to measure guilt. This is the case of the Mosher Guilt Scales (Abramson, Mosher, Abramson, \& Woychowski, 1977), which are focused on guilt as a personality disposition and assess three aspects: Sex-guilt, Hostility and Morality-Conscience. In Brazil, the most recent study found to measure guilt was undertaken by Aquino and Medeiros (2009), in which the authors developed the Multidimensional Scale of Guilt. This instrument, suited to the adult population, views guilt in three dimensions: subjective, objective and temporal. 
Subjective guilt would be the feeling of remorse which is not associated with the actions performed, but with aspects of subjectivity, such as thoughts and feelings. Objective guilt refers to actions performed by people. Finally, temporal guilt relates to the accumulation of daily activities and also to the accumulation of leisure activities, which can be seen as a waste of time.

The diversity of instruments to assess shame and guilt in adolescents is no longer that prominent. Among the rare instruments found to assess shame and guilt and also other self-conscious emotions among adolescents, the Test of SelfConscious Affect Adolescent Version - TOSCA-A (Tangney, Wagner, Gavlas, \& Gramzow, 1991) can be highlighted. This is a questionnaire with 15 descriptions of scenarios, being 10 negative and five positive, which assesses proneness to shame, guilt, alpha pride (pride of themselves, of how they are) and beta pride (pride of a specific behavior).

No instruments were found in the literature to assess shame and guilt separately and which showed evidence of validity for use with adolescents, especially in the Brazilian context. Furthermore, the small conceptual differences between the constructs, at times used as synonyms, raise questions about the possibility of empirical differentiation between the feelings. With this in mind, this study was developed with the aim of: (1) developing and verifying the psychometric properties of scales to assess shame and guilt among Brazilian adolescents and (2) empirically testing the independence of these two constructs.

\section{Method}

\section{Participants}

Five hundred and eighty students, aged between 13 and 18 years $(M=16.0 ; S D=1.19)$, participated in this study, $55.6 \%$ female, and all of them were attending high school in the Brazilian states of Parana, Rio de Janeiro and Rio Grande do Sul. 54.7\% of the participants attended public schools and the remainder were from private schools.

\section{Instruments}

A self-administered questionnaire with closed sociodemographic questions, such as: gender, age, level of education/grade and the first versions of the following scales:

Shame Scale for Adolescents (EVA): The first version of the scale included 15 items in the form of statements. Subsequent to the statements, there was a five-point scale for the participants to score how much they considered the statements to represent feelings or behaviors that occurred to them, being that point 1 meant never occurs and point 5 always occurs. The final version of the scale is composed of eight items (Attachment A).

Guilt Scale for Adolescents (ESCA): The first version of this scale was composed of 17 items in the form of statements. Subsequent to the statements, there was a scale with five points for the participants to score how much they considered the statements to represent feelings or behaviors that occurred to them, being that point 1 meant never occurs and point 5 always occurs. The final version of this scale is composed of 11 items, divided into two factors: Recognition of Mistake and Regret (Attachment B).

The final versions of the scale include the items originating in these first versions. In both scales, the closer the score approaches five, the higher the levels of emotion.

Development of the scale items: For the development of the scale items, a data survey was undertaken, involving 114 youngsters from the city of Porto Alegre, in which they were asked to define shame and guilt in their own words, as suggested by Pasquali (1998). Based on the answers to the open questions about the definition, two lists of answers were developed, related to the definitions given to the two constructs. Then, the answers with similar meanings were grouped and, from these groups, statements were created and composed the items of the scale. In addition, items created based on the literature concerning shame (Costa, 2008; Stoeber et al., 2007) and based on a Brazilian instrument concerning guilt (Aquino \& Medeiros, 2009) were added to the list of answers representing the constructs. From the list of items, the researchers selected the largest number of items with the smallest amount of content repetition among them, resulting in 15 items concerning Shame and 17 concerning Guilt.

\section{Procedure}

Data collection. The heads of the schools were contacted in order to verify the feasibility of the research. In the schools where there was acceptance, the pedagogical coordinators were contacted and the groups to be approached, as well as the days for data collection were defined. Informed Consent Forms were provided to the parents or legal guardians of the adolescents, and the agreement of the students was requested. The participants answered the questionnaires in the classroom during school hours. Initially, a rapport for the presentation of the research and procedures was performed, explaining the voluntary nature of the participation. Only the adolescents who had provided a signed Informed Consent Form participated in the study. Most of the participants completed the instruments in less than 20 minutes.

Data analysis. In order to check the validity of the constructs and their possible independence, factorial analyses were performed, using the Principal Axis Factoring method and Oblimin rotation, with the items of each scale separately and later with the items of the two scales together. Taking into account the theoretical developments of shame and guilt, the Oblimin rotation was chosen as these two constructs were considered correlated. In addition, this rotation would allow the rise of orthogonal factors, if this were the case (Pasquali, 2005). The averages and standard deviations of the scales and their respective Alpha Coefficients (Cronbach, 1951) were calculated to verify the reliability of these 
instruments. Finally, Pearson correlations were performed between shame and guilt with the purpose of verifying the level of relationship between the constructs.

\section{Ethical Considerations}

The research complied with the requirements with respect to the Ethics in Research involving Human Beings, in accordance with national resolution number 196/96 of the National Research Ethics Commission (CONEP) and with resolution number 016/2000 of the Federal Psychology Council. The approval of the Research Ethics Committee of the Psychology Institute at the Universidade Federal do Rio Grande do Sul was obtained, under registration number 2011032.

\section{Results}

\section{Shame Scale for Adolescents}

The data relating to the shame scale were shown to be suitable to its factorization, $K M O=.89$. Also, Bartlett's test of sphericity $(p<.001)$ suggests suitability of the correlation matrix of the items. Based on Kaiser's criteria (1960), factors with eigenvalue $>1$, and Cattell (1966), analysis of sediment graphs, the rise of a single factor was observed. Seven items, which did not have factorial loadings greater than .30, were removed; at the end, eight items explained $44.2 \%$ of the data variance, as can be seen in Table 1 . When analyzing the contents of the items removed from subsequent analysis, it was verified that, in general, these items had ambiguous content in the definition of the emotion, moving the information contained in the item to a perception of other people's shame. The final version of the scale presented a satisfactory reliability rate (Cronbach, 1951), with an alpha coefficient $=.86$.

Table 1

Factor Loadings and Commonalities of Shame Scale Items From Principal Axis Factoring Analysis With Oblimin Rotation

\begin{tabular}{lcc}
\hline Items & Loadings & $\mathrm{h}^{2}$ \\
\hline Sometimes I feel prevented from doing & .76 & .58 \\
something out of fear of being judged. & & \\
I am afraid of being judged for my actions. & .75 & .56 \\
I am afraid of being judged for who I am. & .73 & .53 \\
Sometimes I do not do something that I wish & .72 & .52 \\
to do out of fear of what other people will say & & \\
or thing. & & \\
I am afraid of what people may say or think of me. & .70 & .49 \\
I feel insecure when other people pay attention & .55 & .31 \\
to me. & & \\
I feel bad for some action I have committed & .55 & .30 \\
and other people saw or heard about it. & & \\
I feel inferior to other people. & .50 & .25 \\
\hline Quantity of items & 8 & \\
Eigenvalue & 4.06 & \\
\% Explained Variance & 44.2 & \\
Cronbach's Alpha Coefficient & .86 & \\
\hline
\end{tabular}

The average in the shame scale for this sample was 2.83 $(S D=0.93)$. When comparing the levels of shame between the genders, it was observed that female adolescents $(M=2.91$; $S D=0.94)$ had significantly higher average than male adolescents $(M=2.73 ; S D=0.91), t(572)=2.29 ; p<.05 ; d=0.19$. There were no significant correlations between the age of the participants and the scores of shame, $r(574)=.08 ; p=.06$.

\section{Guilt Scale for Adolescents}

The data related to the guilt scale were also shown to be suitable to its factorization, $K M O=.87$; Bartlett's test of sphericity: $p<.001$. Two factors emerged based on the criteria of Cattell (1966) and Kaiser (1960), which accounted for $39.2 \%$ of the variance. Six items presented factor loadings lower than .30 and were removed from the final version of the scale. It was observed that the items excluded from the subsequent analysis, in general, had general contents, for example, I feel guilty for something I have done. The two factors of the scale, called Recognition of Mistake (Factor 1) and Regret (Factor 2), were mutually correlated, $r(571)=.53 ; p<.001$, with appropriate accuracy rates (Cronbach, 1951), as shown in Table 2.

Table 2

Factor Loadings and Commonalities of Guilt Scale Items From Principal Axis Factoring Analysis With Oblimin Rotation

\begin{tabular}{ll}
\hline \multirow{2}{*}{ Items } & \multicolumn{2}{c}{ Loadings } \\
\cline { 2 - 3 } & Factor 1 Factor 2 \\
\hline
\end{tabular}

I feel bad when I want to do
something that I know is not right.

I feel bad after having done

.61

.

something wrong.

Sometimes I feel guilty when I want to do something bad.

.58

I feel bad when I know I should have done something but have not done it.

When I feel guilty for having harmed someone, I try to repair the damages caused.

I feel guilty for something I have not done but I know I should have done.

I feel remorseful for having done something I should not have done.

I regret to have taken some actions.

I feel guilty for having done things that nobody knows that I have done.

I would like to have not done some things that I have done.

I feel bad for having done something even thought I knew it was not the right thing to do.

\begin{tabular}{lcc}
\hline Quantity of items & 7 & 4 \\
Eigenvalues & 4.15 & 1.35 \\
\% Explained Variance & 32.4 & 6.82 \\
Cronbach’s Alpha Coefficient & .78 & .75 \\
\hline
\end{tabular}

Note. Factor loadings $<.30$ were omitted. 
The participants showed an average score of 3.39 ( $S D=0.83$ ) for the Recognition of Mistake factor; and 2.95 $(S D=0.99)$ for the Regret factor. There was no significant difference between genders in relation to the Regret factor $t$ $(571)=0.51 ; p=.61 ; d=0.04$; however, in relation to the Recognition of Mistake factor, female adolescents $(M=3.51$; $S D=0.94$ ) showed significantly higher averages than male adolescents $(M=3.25 ; S D=0.83), t(569)=3.78 ; p<.001$; $d=0.32$. The correlations between the age of the adolescents and the scores for the guilt factors Recognition of Mistake and Regret were not significant, with $r(571)=-.03 ; p=.47$ and $r(573)=-.07 ; p=.09$, respectively.

\section{Independence of Constructs}

In order to test the independence of the constructs shame and guilt, a factorial analysis was performed, also using the Principal Axis Factoring method and Oblimin rotation, including all items of the final versions of the two scales. Initially, it was verified that the data were suitable for factorization: $K M O=.90$; Bartlett's test of sphericity: $p$ $<.001$. Three factors appeared with eigenvalue $>1$, which can also be seen through the sediment graphs in Figure

Table 3

Items and Factor Loadings of the Shame and Guilt Scales From Principal Axis Factoring Analysis With Oblimin Rotation

\begin{tabular}{|c|c|c|c|}
\hline \multirow[t]{2}{*}{ Items } & \multicolumn{3}{|c|}{ Loadings } \\
\hline & Shame & Recognition of Mistake & Regret \\
\hline Shame 1 & .80 & & \\
\hline Shame 4 & .76 & & \\
\hline Shame 2 & .70 & & \\
\hline Shame 5 & .69 & & \\
\hline Shame 3 & .69 & & \\
\hline Shame 6 & .56 & & \\
\hline Shame 8 & .43 & & \\
\hline Shame 7 & .39 & & -.34 \\
\hline Guilt 1 & & .62 & \\
\hline Guilt 2 & & .58 & \\
\hline Guilt 3 & & .57 & \\
\hline Guilt 4 & & .53 & \\
\hline Guilt 5 & & .50 & \\
\hline Guilt 6 & & .50 & \\
\hline Guilt 7 & & .44 & -.37 \\
\hline Guilt 9 & & & -.71 \\
\hline Guilt 8 & & & -.64 \\
\hline Guilt 10 & & & -.61 \\
\hline Guilt 11 & & & -.40 \\
\hline Eigenvalues & 6.07 & 2.03 & 1.26 \\
\hline $\begin{array}{l}\text { \% Explained } \\
\text { Variance }\end{array}$ & 29.6 & 9.07 & 3.67 \\
\hline
\end{tabular}

Note. Factor loadings $<.30$ were omitted. The number of the items is consistent with the order of their presentation in Table 1 and 2.
1. These three factors were respectively composed of the items of the scales Shame, guilt factor Recognition of Mistake and guilt factor Regret, as shown in Table 3. Shame was positively correlated with both the guilt factor Recognition of Mistake $r(571)=.34 ; p<.001$, and the Regret factor, $r(573)=.50 ; p<.001$.

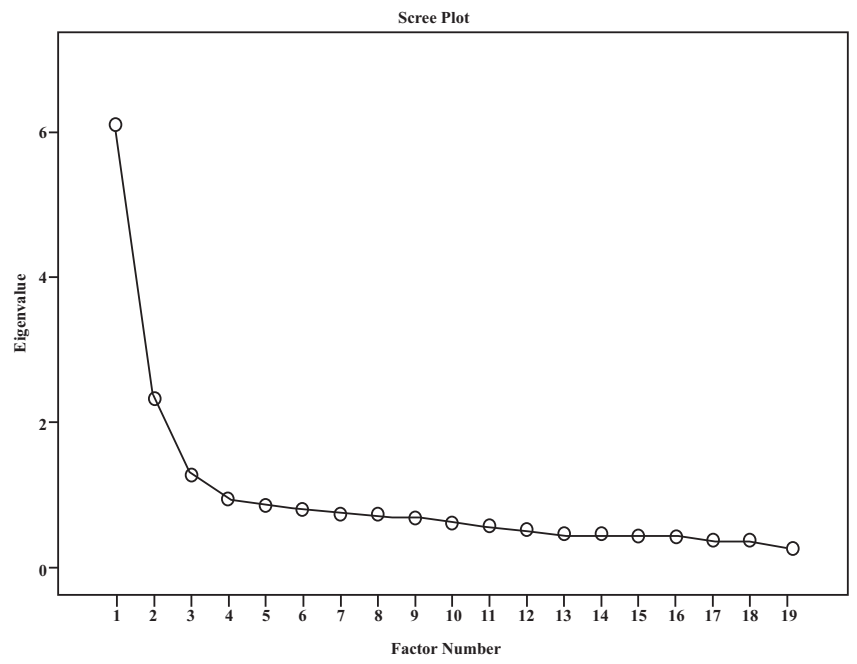

Figure 1. Scree Plot of the factorial analysis of all items on the shame and guilt scales.

\section{Discussion}

This study aimed to develop and verify-the psychometric properties of the scales to assess shame and guilt in Brazilian adolescents, as well as to empirically test the independence of these two constructs. Initially, appropriate evidences of validity and satisfactory levels of accuracy were found in the developed measures. Then, analyses were performed to test the independence of the two constructs. Based on a factorial analysis, which included all the items developed for the Shame and Guilt scales, it was found that the items associated with each of these moral emotions were grouped into different dimensions. In addition to a factorial structure suggesting the independence of these constructs, the correlations between the dimensions of the assessed emotions were shown to be only moderate. These findings, together with the theoretical characteristics that distinguish between these two moral emotions, emphasize the empirical independence of shame and guilt (Costa, 2008; Stoeber et al., 2007; Tangney \& Tracy, 2012).

The development of both the shame and guilt scales followed the steps suggested by Pasquali $(1998,2010)$ for the development of items. Initially, a survey was carried out with the target population about the representations concerning the constructs and, subsequently, a pool of items was developed based on these representations and on the theoretical definitions of the constructs. After the application of the first versions, a series of statistical analyses (factorial analyses and internal consistency calculations) was conducted in order to determine the best configuration of items for the scales. Thus, 
items which did not have appropriate psychometric properties were removed from the final versions of the scales, mainly using the minimum factor loading criterion of 0.30 .

The shame scale is aimed at assessing the feeling of embarrassment in situations where there was the chance of judgment by third parties, besides a feeling of powerlessness in expressing themselves due to the fear of being judged by others. This definition of the construct is in accordance with the conceptions of other authors in relation to Shame (Costa, 2008; Stoeber et al., 2007; Tangney \& Tracy, 2012).

When comparing the shame averages between the genders, female adolescents showed higher levels of shame than male adolescents. The pressures of socialization that encourage shame and inhibition, more predominant among women, can explain this finding. In line with this argument, Woien et al. (2002) emphasized the positive correlation between shame and stress. The study undertaken by Calais, Andrade e Lipp (2003) showed the differences between genders in relation to stress and found that women had higher levels than men, regardless of age. Such findings, in conjunction with those of this study, showed that, since an early age, and regardless of social pressures or inherent propensities, women more than men are concerned about the possibility of being judged for their behavior.

The guilt scale presented two factors. The first factor, called Recognition of Mistake, was composed of items related to the feeling of discomfort and the understanding of having committed a bad action. This factor has a content that is similar to the concept used by Costa (2008) to define guilt, which considers that this emotion is related to a concern about a specific violation. In contrast, factor 2, called Regret, is composed of items that assess the perception of feelings of regret after having conducted an inappropriate behavior. This factor is consistent with the idea proposed by Stoeber et al. (2007), who argue that guilt refers to feelings of regret and remorse, and these feelings may motivate people to repair.

In terms of the average guilt scores between the genders, there were no differences with respect to the Regret factor. Concerning the other guilt factor (Recognition of Mistake), female adolescents showed higher averages than male adolescents. This finding may be related to the evidence that girls are socially more competent and also more empathic (Cecconello \& Koller, 2000), which would allow them to have more skills to understand the social rules and to have the ability to recognize their mistakes when putting themselves in other people's places.

The correlations between adolescents' age and the scores on the Shame and Guilt scales were not significant. This suggests that age, in this sample, did not affect the recognition of emotions. This result was expected, since the ability to recognize self-conscious emotions is already present in children as young as five, when they are able to distinguish between themselves and others, as well as when they begin to recognize models and standards (Lewis \& Brooks, 1978; Paludo, 2002).

\section{Final Considerations}

Reliable measures were developed to assess Shame and Guilt in adolescents. The fact of having accessed the common sense knowledge about the topics among the procedures used to develop the scale items is highlighted, resulting in the development of items that are appropriate to the current language of the studied population. In addition, the briefness of the instruments, eight items for Shame and 11 items for Guilt, encourages their use in different research contexts, with a reduced chance of the participants becoming bored.

Shame and Guilt have distinct theoretical conceptions and, as shown in this study, this distinction is also empirical. These findings point to the possibility of adolescents feeling both emotions simultaneously and in different contexts. In order to answer this question, further research can use the instruments developed in this study. Furthermore, new studies may be developed, taking into account the accessibility of these emotions, for example, studies aimed at unraveling the effects of these emotions on healthy development and their relations with other behavioral variables.

New studies about shame and guilt in adolescents may overcome the limitations found in this study whilst including measures about related contexts that are revealing of each of these emotions. Lastly, the transitional and cultural feature of every psychometric instrument can be highlighted and changes made to these instruments are encouraged with a view to their improvement.

\section{References}

Abramson, P. R., Mosher, D. L., Abramson, L. M., \& Woychowski, B. (1977). Personality correlates of the Mosher Guilt Scales. Journal of Personality Assessment, 41(4), 375-382. doi:10.1207/s15327752jpa4104_7

Anolli, L. (2003). A vergonha: Quando nossa auto-imagem faz-se em pedaços e o que mais queremos é desaparecer (G. Bertazzo, Trad.). São Paulo: Paulinas.

Aquino, T. A. A., \& Medeiros, B. (2009). Escala de culpabilidade: Construção e validação de construto. Avaliação Psicológica, 8(1), 77-86.

Calais, S. L., Andrade, L. M. B., \& Lipp, M. E. N. (2003). Diferenças de sexo e escolaridade na manifestação de stress em adultos jovens. Psicologia: Reflexão e Crítica, 16(2), 257-263. doi:10.1590/S0102-79722003000200005

Cattell, R. B. (1966). The scree test for the number of factors. Multivariate Behavioral Research, 1(2), 245-276. doi:10.1207/s15327906mbr0102_10

Cecconello, A. M., \& Koller, S. H. (2000). Competência social e empatia: Um estudo sobre resiliência com crianças em situação de pobreza. Estudos de Psicologia (Natal), 5(1), 71-93. doi:10.1590/S1413-294X2000000100005

Costa, C. F. C. D. (2008). As emoções morais: A vergonha, a culpa, e as bases motivacionais do ser humano (Unpublished Master's Thesis). Universidade de Lisboa, Lisboa, Portugal. 
Cronbach, L. J. (1951). Coefficient alpha and the internal structure of tests. Psychometrika, 16(3), 297-334. doi:10.1007/BF02310555

Dela Coleta, J. A., \& Dela Coleta, M. F. (2011). Conhecendo a si e ao outro: Percepção e atribuição de causalidade. In C. V. Torres \& E. R. Neiva (Orgs.), Psicologia social: Principais temas e vertentes (pp. 134-152). Porto Alegre, RS: Artmed.

Imber-Black, E. (1994). Os segredos na família e na terapia familiar (D. Batista, Trad.). Porto Alegre, RS: Artes Médicas.

Kaiser, H. F. (1960). The application of electronic computers to factor analysis. Educational and Psychological Measurement, 20(1), 141-151. doi:10.1177/001316446002000116

Kelley, H. H. (1973). The processes of causal attribution. American Psychologist, 28(2), 107-128. doi:10.1037/h0034225

Krebs, D. L. (2008). Morality: An evolutionary account. Perspectives on Psychological Science, 3(3), 149-173. doi:10.1111/j.1745-6924.2008.00072.x

La Taille, Y. (2006). Moral e ética: Dimensões intelectuais e afetivas. Porto Alegre, RS: Artmed.

Lewis, M. (2008). Self-conscious emotions embarrassment, pride, shame, and guilt. In M. Lewis, J. M. HavilandJones, \& L. F. Barrett (Eds.), Handbook of emotions (3rd ed., pp. 742-756). New York, NY: Guilford.

Lewis, M., \& Brooks, J. (1978). Self-knowledge and emotional development. In M. Lewis \& L. A. Rosenblum (Eds.), The development of affect: The genesis of behavior (pp. 205226). New York, NY: Plenum.

Paludo, S. S. (2002). A expressão das emoções morais de crianças em situação de rua (Unpublished Master's Thesis). Universidade Federal do Rio Grande do Sul, Porto Alegre, RS.

Paludo, S. S. (2008). Emoções morais e gratidão: Uma nova perspectiva sobre o desenvolvimento de jovens em situação de risco pessoal e social (Unpublished Doctoral Dissertation). Universidade Federal do Rio Grande do Sul, Porto Alegre, RS.

Pasquali, L. (1998). Princípios de elaboração de escalas psicológicas. Revista de Psiquiatria Clínica (São Paulo), 25(5), 206-213.

Pasquali, L. (2005). Análise fatorial para pesquisadores. Brasília, DF: LabPAM.

Pasquali, L. (2010). Instrumentaçãopsicológica: Fundamentos e práticas. Porto Alegre, RS: Artmed.

Robinson, R., Roberts, W. L., Strayer, J., \& Koopman, R. (2007). Empathy and emotional responsiveness in delinquent and non-delinquent adolescents. Social Development, 16(3), 555-579. doi:10.1111/j.1467-9507.2007.00396.x

Santos, A. S. (2009). Diferenças individuais na tendência para a vergonha e culpa: Antecedentes motivacionais (Unpublished Master's Thesis). Universidade de Lisboa, Lisboa, Portugal.
Stoeber, J., Harris, R. A., \& Moon, P. S. (2007). Perfectionism and the experience of pride, shame, and guilt: Comparing healthy perfectionists, unhealthy perfectionists, and nonperfectionists. Personality and Individual Differences, 43(1), 131-141. doi:10.1016/j.paid.2006.11.012

Tangney, J. P., \& Dearing, R. L. (2004). Shame and guilt. New York, NY: Guilford.

Tangney, J. P., Stuewig, J., \& Mashek, D. J. (2007). Moral emotions and moralbehavior. Annual Review of Psychology, 58, 345-372. doi:10.1146/annurev.psych.56.091103.07014

Tangney, J. P., \& Tracy, J. L. (2012). Self-conscious emotions. In M. R. Leary \& J. P. Tangney (Eds.), Handbook of self and identity (2nd ed., pp. 446-477). New York, NY: Guilford.

Tangney, J. P., Wagner, P., Fletcher, C., \& Gramzow, R. (1992). Shames into anger? The relation of shame and guilt to anger and self-reported aggression. Journal of Personality and Social Psychology, 62(4), 669-675. doi:10.1037/0022-3514.62.4.669

Tracy, J. L., \& Robins, R. W. (2006). Appraisal antecedents of shame and guilt: Support for a theoretical model. Personality and Social Psychology Bulletin, 32(10), 1339-1351. doi:10.1177/0146167206290212

Tangney, J. P., Wagner, P. E., Gavlas, J., \& Gramzow, R. (1991). The Test of Self-Conscious Affect for Adolescents (TOSCA-A). Fairfax, VA: George Mason University.

Wright, D. (1971). The psychology of moral behavior. New York, NY: Penguin Books.

Woien, S. L., Ernst, H. A. H., Patock-Peckham, J. A., \& Nagoshi, C. T. (2003). Validation of the TOSCA to measure shame and guilt. Personality and Individual Differences, 35(2), 313-326. doi:10.1016/S0191-8869(02)00191-5

Lorena Maria Laskoski is an Educator and M.Sc. in Psychology in the Graduate Program in Psychology at the Universidade Federal do Rio Grande do Sul.

Jean Carlos Natividade is a Ph.D student in the Graduate Program in Psychology at the Universidade Federal do Rio Grande do Sul.

Claudio Simon Hutz is a Professor at the Institute of Psychology of the Universidade Federal do Rio Grande do Sul.

Received: May $14^{\text {th }} 2012$

$1^{\text {st }}$ Revision: Nov. $19^{\text {th }} 2012$

Approved: Nov. 28 2012

How to cite this article:

Laskoski, L. M., Natividade, J. C., \& Hutz, C. S. (2013). Development of instruments to assess shame and guilt in adolescents: Empirical differences between the constructs. Paidéia (Ribeirão Preto), 23(55), 171-178. doi:10.1590/1982-43272355201304 


\section{Attachment A}

\section{Escala de Vergonha para Adolescentes (EVA)}

Por favor, leia as frases abaixo e assinale nas escalas o quanto você julga que elas ocorrem com você. Observe que a escala varia de 1 (Nunca ocorre) a 5 (Sempre ocorre). Não há respostas certas ou erradas, o importante é você responder com sinceridade. Lembre-se que você pode usar os números intermediários (2, 3 e 4) para expressar níveis intermediários de frequência das situações.

Eu me sinto mal por alguma ação que cometi e outras pessoas viram ou ficaram sabendo.

Nunca |_1_|_2_|_3_|_4_|_5_| Sempre

Tenho receio do que os outros podem dizer ou pensar de mim.

Nunca |_1_|_2_|_3_|_4_|_5_| Sempre

Tenho medo de ser desaprovado por minhas atitudes.

Nunca |_1_|_2_|_3_|_4_|_5_| Sempre

Às vezes eu me sinto impedido de fazer algo por medo de ser julgado.

Nunca |_1_|_2_|_3_|_4_|_5_| Sempre

Eu me sinto inferior às outras pessoas.

Nunca |_1_|_2_|_3_|_4_|_5_| Sempre

Algumas vezes deixo de fazer algo que gostaria, por medo do que os outros vão falar ou pensar.

Nunca |_1_|_2_|_3_|_4_|_5_| Sempre

Tenho medo de ser desaprovado pelo que sou.

Nunca |_1_|_2_|_3_|_4_|_5_| Sempre

Eu me sinto inseguro quando outras pessoas prestam atenção em mim.

Nunca |_1_|_2_|_3_|_4_|_5_| Sempre

Average calculation:

To calculate the arithmetic average of the items.

\section{Attachment B}

\section{Escala de Culpa para Adolescentes (ESCA)}

Por favor, leia as frases abaixo e assinale nas escalas o quanto você julga que elas ocorrem com você. Observe que a escala varia de 1 (Nunca ocorre) a 5 (Sempre ocorre). Não há respostas certas ou erradas, o importante é você responder com sinceridade. Lembre-se que você pode usar os números intermediários (2, 3 e 4) para expressar níveis intermediários de frequência das situações.

Eu me arrependo por ter tomado algumas atitudes.

Nunca |_1_|_2_|_3_|_4_|_5_| Sempre

Eu me sinto mal por ter feito algo mesmo sabendo que não era a coisa certa a ser feita.

Nunca |_1_|_2_|_3_|_4_|_5_| Sempre

Quando eu me sinto culpado por ter prejudicado alguém tento reparar o dano.

Nunca |_1_|_2_|_3_|_4_|_5_| Sempre

Eu me sinto mal após ter feito algo errado.

Nunca |_1_|_2_|_3_|_4_|_5_| Sempre

Eu me sinto mal quando tenho vontade de fazer algo que sei que não é o certo.

Nunca |_1_|_2_|_3_|_4_|_5_| Sempre

Gostaria de não ter feito algumas coisas que fiz.

Nunca |_1_|_2_|_3_|_4_|_5_| Sempre

Eu me sinto mal quando sei que deveria ter feito algo, mas não o fiz.

Nunca |_1_|_2_|_3_|_4_|_5_| Sempre

Sinto remorso por ter feito algo que não deveria.

Nunca |_1_|_2_|_3_|_4_|_5_| Sempre

Às vezes eu me sinto culpado quando tenho vontade de fazer alguma coisa ruim.

Nunca |_1_|_2_|_3_|_4_|_5_| Sempre

Eu me sinto culpado por ter feito coisas que ninguém sabe que fiz.

Nunca |_1_|_2_|_3_|_4_|_5_| Sempre

Sinto culpa por algo que não fiz e sei que deveria ter feito.

Nunca |_1_|_2_|_3_|_4_|_5_| Sempre

Average Calculations:

Regret factor: arithmetic averages of the items 1, 2, 6 and 10.

Recognition of Mistake factor: averages of the items 3, 4, 5, 7, 8, 9 and 11. 